\title{
Feminism and the Hard-Boiled Genre: Breakdown in Sara Paretsky's Breakdown
}

\author{
Maryam Soltan Beyad ${ }^{1}$, Mohsen Jabbari ${ }^{2}$ \\ Department of English, Faculty of Foreign Languages and Literature, \\ University of Tehran, Tehran, Iran \\ 1'msbeyad@ut.ac.ir, ${ }^{2}$ m.jabbari@alumni.ut.ac.ir
}

\begin{abstract}
As feminist re-writings of the genre of crime fiction (mostly the hard-boiled) from the 1980s onward, Sara Paretsky's Warshawski novels provide a fertile field for critical and cultural studies. The aims of this paper are twofold: first, it traces the generic influences on her latest novel Breakdown (2012) beyond the obvious male precursors of the hard-boiled (Dashiell Hammett and Raymond Chandler) of the interwar period to the Gothic vogue in the early $19^{\text {th }}$ century; and second, drawing on Roland Barthes's notion of readerly/writerly texts, Pierre Macherey's critique of ideology in realist fiction, and Fredric Jameson's dialectical view of genre, it teases out the symptomatic fissures and contradictions in Paretsky's novel which betray the text's inability to ultimately resist the ideology it intends to subvert.
\end{abstract}

Keywords: hard-boiled genre, feminism, ideology, realist fiction

\section{INTRODUCTION: The Hard-Boiled Genre}

The Great Depression of the 1930s in the United States led to unprecedented emotional and social distress, and, consequently, an increase in crime and punishment. Such harsh living circumstances encouraged, even necessitated, the production of a cheap source of entertainment which was affordable, on the one hand, and reflective of social ills, on the other. In the early 1920s, a generation of American male writers was already printing their clumsy tales in cheap wood-pulp paper magazines which had become popular during WWI. By the mid-20s, the "pulps" had begun to address America's large working-class audience through their depiction of the hard-boiled U.S. private eye, whose popularity "reflected the rise of the gangster in American society with the coming of Prohibition in 1920 and its accompanying civic and police corruption" (Symons 144).

Black Mask magazine, founded by the literary critic H. L. Mencken and theater critic George Jean Nathan, played a particularly important role in developing the characteristically American hard-boiled detective fiction. Famously, Mencken had gotten into the magazine business for financial gain, and gave up his project within six months. In this short period, the magazine portrayed, among others, Caroll John Daly's (1889-1958) private investigator Race Williams, the tough and cynical figure considered by many scholars as the first hard-boiled detective. He was always armed and took great pleasure in violence, his motto being: "You can't make a hamburger without grinding a little meat" (qtd. in Symons 144). He was sure his victims deserved his savage treatment and his misogyny was to be followed by later PIs. 
Joseph T. Shaw, Black Mask's later editor, made a great contribution to the development of this genre by helping his authors perfect the hard-boiled type of stories. In addition to other writers, Shaw supported the careers of Dashiell Hammett (1894-1961) and Raymond Chandler (1888-1959), the two masters of the hard-boiled detective fiction. Shaw encouraged the writers of his magazine to use stripped-down prose, plots with rough physical action and credible, flesh-and-bone characters (145). Dashiell Hammett's brutal private eye Sam Spade became an American folk hero, a self-made man with a hooked nose and Vshaped face. In Spade, Hammett created a cruel "code of honor" which was subsequently adopted by later hard-boiled writers. "Spade," as Mitzi M. Burnsdale writes, "is oblivious to any kind of sentiment or softness, unafraid of death, unfettered by the desire for wealth, and unaffected by the lure of sex" (Dictionary of Fictional Detectives 21). While he was writing for Black Mask, Hammett also created The Continental Op, a nameless detective employed by the Continental Detective Agency, which was partly based on the Pinkerton Agency where Hammett had worked for some years. The Op is short, fat, ruthless, and like Spade, unaffected by feminine wiles, telling one hopeful seductress, "You think I'm a man and you're a woman. That's wrong. I'm a man-hunter and you're something that's been running in front of me. There's nothing human about it" (qtd. in Burnsdale 39).

A number of writers followed Hammett's example with lesser and greater success. Mickey Spillane is a case in point. Famously or infamously, he created perhaps the toughest private investigator, Mike Hammer, whose violent behavior exceeded both Sam Spade and the Continental Op. "In his debut novel I, the Jury (1947), Hammer casually gut-shoots a woman, then as she is dying tells her, 'It was easy." (39). His Hammer series went on to become bestsellers in the coming years. Trying to account for such success, James L. Traylor and Max Allan Collins have gone so far as to comment that Spillane's Hammer "captured the psyche of America, from its loss of innocence after World War II to the late 1980s loss of purpose and directions. His books offer a savagely lyrical depiction of the wounded American soul" (qtd. in Herbert 185).

Raymond Chandler (1988-1959), who sold his first story, "Blackmailers Don't Shoot," to Black Mask in 1933, had bigger hopes for the mystery genre and his series hero Philip Marlowe. As Andrew Pepper states, Chandler "dismissed the English 'Cheesecake Manor' detective novels of the golden age as contrived and whimsical and praised Dashiell Hammett...for trying to write 'realistic mystery fiction,' for being 'spare, frugal, hardboiled,' and for writing 'scenes that seemed never to have been written before." (Companion to Crime Fiction 140). He felt that Hammett's hard-boiled detective stories reflected real life: "Hammett gave murder back to the kind of people that commit it for reasons, not just to provide a corpse; and with the means at hand, not hand-wrought dueling pistols, curare and tropical fish" (qtd. in Murphy 93). Further, in his 1944 Atlantic Monthly essay "The Simple Art of Murder," which is often read as a kind of hard-boiled manifesto, he gave his famous definition of the hard-boiled private eye:

But down these mean streets a man must go who is not himself mean, who is neither tarnished nor afraid. The detective in this kind of story must be such a man. He is the hero; he is everything. He must be a complete man and a common man and yet an unusual man. He must be, to use a rather weathered phrase, a man of honour. (qtd. in Scaggs 56)

Based on the definition above, he created Philip Marlowe, an attractive, single man who was fired for disobedience from his job as a D.A.'s investigator in Los Angeles County, and loves classical music. Moreover, he is a tough-talking, wisecracking PI addicted to alcohol. Little 
did Chandler know probably that these characteristics (the tough talk, in particular) would make it all the way to Sara Paretsky's V. I. Warshawski in the $21^{\text {st }}$ century.

With this brief history in mind, a few issues concerning the hard-boiled are worth discussing. To begin, why and how exactly is it an American genre? John Scaggs in his Crime Fiction gives three reasons. He argues that the hard-boiled fiction is a translation of "the romanticism of the Western into a modern urban setting". Thus, the first purely American feature is "the Californian setting of most of the early hard-boiled novels". Next, since the tough talk is an integral part of the PI, "the American vernacular" turns into a vital characteristic of this genre, making it specifically American. And third is "the portrayal of crimes that were increasingly becoming part of the everyday world of early twentieth-century America" (57).

To move on to the next issue, how does the classic detective story differ from the hard-boiled story? Scaggs comes up with three answers at least: first, in the classic one the plot is privileged over the characters whereas in the hard-boiled the plot is decentered and pushed to the margins; second, the former type depends on "analytic deduction" while the latter contains "little or no analysis of clues" (59); and third, the hard-boiled PI is "no longer an eccentric or wealthy amateur" like Miss Marples or Hercule Poirots and, instead, he is "a professional investigator who works for a living, and, more significantly, who works for himor herself" (60).

\section{FEMINIST APPROPRIATIONS}

With the great surge in liberal feminism in the 1960s, an impetus emerged to re-write the literary canon and to re-claim male-dominated discursive sites. The Chandler-Hammett tradition discussed in the previous section, which is associated with a cynical, worldly-wise protagonist who speaks in a tough, gritty, colloquial way and possesses great confidence and independence of mind, presented itself most readily, as Lee Horsley states, "to writers interested in female empowerment" (Twentieth-Century Crime Fiction 248).

According to Stephen Knight, "The first major move in feminist crime fiction was made by Marcia Muller with Edwin of the Iron Shoes (1977)" (Crime Fiction: 1800-2000 166). When Muller introduced her professional detective Sharon McCone, liberal feminist ideas had become widespread, which enabled Muller to establish the major features of the woman private eye in McCone. Knight summarizes these features-which are equally applicable to Sara Paretsky's V. I. Warshawski as well as Sue Grafton's Kinsey Millhone -as follows:

She is mature and experienced as well as inquisitive and skillful; she is wary of but not fully opposed to the police; she has sexual identity and also an extended connection with family and, especially, friends, both women and men; she has substantial empathy with victims of crime; she pursues her inquiries with courage, often being alarmed or physically hurt in the process; the crimes she confronts can be violent and distressing, and unlike the male private-eye tradition they derive mostly from a real combination of urban corruption and personal betrayals. She embodies an optimistic sense that crime can be contained and a better life enjoyed for women, even in the big bad city, even among the secrets and dangers of modern human interaction. (166-7) 
Sue Grafton and Sara Paretsky began publishing their novels at the same time in 1982. Grafton is a television writer and, adopting the genre of the hard-boiled, has produced an ongoing alphabetical series, beginning with $A$ is for Alibi (1982), and her latest novel is $V$ is for Vengeance (2012). Her androgynously named PI is Kinsey Millhone, whose cases mostly derive from her connection with an insurance company. Like Paretsky's private eye, she is fit and lives alone with a quasi-family. However, she is less overtly a feminist than she is a Chandlerian detective which has led to mixed responses to her works.

With the transition from a male PI to a female PI in place after Muller's first novel, Sara Paretsky created a private eye who was a more aggressive and assertive feminist. Whereas McCone lives in the quiet of San Francisco, Warshawski works in the harsh din of Chicago. Warshawski's first name, "unlike Sharon," which is a patently female name, is V. I., a more neutral name, and to emphasize this fact, Paretsky has her PI respond only "to the androgynous Vic" (167). Like McCone, she is adroit in tracing mysteries in files. Warshawski is a former defense lawyer and has been active in abortion rights movement of the $60 \mathrm{~s}$ and 70s. Unlike their male predecessors, however, both McCone and Warshawski have a ring of close friends and neighbors who act as their surrogate family. Though not as sociable as McCone, Warshawski has casual friends from work or from the past, an occasional lover and useful journalist friend by the name of Murray Ryerson (who plays an important part in Breakdown), a close woman friend named Lotty Herschel (who is a doctor and refugee from Nazism), and an elderly neighbor called Mr. Contreras who constantly worries about her safety and looks after her Labrador.

Paretsky's achievement has been considerable, a fact which may be attested to by both the critical and popular reception of her novels. On the same token, Knight notes two more subtle and revealing points concerning the publication of Paretsky's novels. To begin, "[t]hough she finished the first novel by 1980, it took two years to be published" (169), implying how disturbing Paretsky's feminist PI was. Next, it took nine years from the first appearance of V. I. Warshawski in a bestseller novel for Hollywood to welcome her. And when they finally did, the result was satisfactory neither to Paretsky nor to her fans:

[T]he 1991 film V. I. Warshawski...not only condensed and thoroughly garbled the plots of the first two novels, added a long and mindless boat-chase and cast Kathleen Turner in man-mad mode as V. I., but as further sexist containment invented Boom-Boom's daughter to show that V. I. could still be an all-American surrogate mother. (169)

Before a fuller treatment and evaluation of Sara Paretsky and her private investigator in terms of their success in subverting the patriarchal ideology, it is necessary to determine how adaptable the genre of the hard-boiled actually is. Two influential critical works (Maureen T. Reddy's Sisters in Crime: Feminism and the Crime Novel and Kathleen Gregory Klein's The Woman Detective: Gender and Genre) were published in 1988, both of which responded to the above question, and whose opposing answers have shaped the current dichotomous view of feminist appropriations of hard-boiled detective fiction. In The Woman Detective, Klein argues that due to the inherent conservativeness of this genre, the effects of placing a woman at its center are far from radical. "Klein," as Merja Makinen writes, "accepts the Frankfurt School thesis of popular culture: "the producers...have a vested interest in certain arrangements of the status quo which they are unwilling to see challenged in the materials they finance"" (Feminist Popular Fiction 106). This belief on the part of Klein leads her to the conclusion that the ideology embedded in this genre overcomes the feminist counter-ideology. Reddy also maintains that detective fiction is conservative in its outlook; nonetheless, she leaves room for resistance and appropriation. 


\section{READERLY VERSUS WRITERLY: Roland Barthes and the Hard-Boiled Genre}

To what extent does the hard-boiled genre lend itself to cultural and political appropriation? This question has continued to be posed since 1988 and contending responses have been suggested. On the one hand, it has been argued that crime fiction in general suffers from two features which render it inflexible and unsuitable in advancing political causes: conservatism, since the story needs a resolution whereby the status quo is restored, and masculinism, because the classic PIs are not only almost exclusively male but also misogynistic. On the other hand, given the success of authors such as Sara Paretsky and Sue Grafton, an equally strong case has been made in favor of the adaptability of this genre. I would like to assert (in agreement with Scaggs, Willett and Christianson) that new insight might be gained into this debate by drawing on the Barthesian contrast between the readerly and the writerly texts.

According to Barthes, there are two types of texts: the readerly (lisible) and the writerly (scriptible), each of which encourages a different kind of reading. The readerly text invites a passive reader who is inclined to accept the text's meanings as already determined, "[p]lung[ing] him into a kind of idleness" and leaving him "with no more than the poor freedom either to accept or reject the text" (qtd. in Scaggs 74). This type of text typically reaffirms the ideology entrenched in it; further, it attempts to naturalize that ideology and make it seem commonsensical. Contrary to the readerly text, the writerly text aims "to make the reader no longer a consumer, but a producer of the text". This kind of text encourages the reader to assume an active role in rewriting and revising the text in order to make sense of it. In other words, it invites the reader to participate in the construction of meaning.

Along this line of argument, the mystery novel, since its ultimate goal is narrative closure in solving the crime, falls into the category of the readerly text; however, it is less easy to give the hard-boiled novel the same label. Scaggs enumerates several reasons in favor of viewing the hard-boiled novel as a writerly text:

In the hard-boiled novel the private eye achieves only partial understanding or limited and temporary success. Furthermore, the characteristic first-person narrative of the hard-boiled novel is constructed around the divided, fragmented figure of the private eye, resulting in a multivalent text... (75)

The hard-boiled novel, therefore, can be considered writerly, "whose gaps and fissures encourage the reader to enter into the production of meaning."

In a similar vein, Scott R. Christianson in his article, "A Heap of Broken Images: Hardboiled Detective Fiction and the Discourse(s) of Modernity", likens the hard-boiled to the fragments of The Wasteland. He finds the "isolated modern hero sitting before a spectacle of modern chaos and trying to make sense of it all" resembling "the posture of the autonomous and lonely hardboiled detective" (The Cunning Craft 142). The poet's desire to organize and cohere experience, reflected in the actions of the Fisher King and Tiresias in T. S. Eliot's poem, bring to mind the narrative efforts of a private investigator. "One of the ways of restoring or maintaining order," Scaggs says, "is the containment of the 'other' that threatens the social order, and such a strategy of containment is evident in crime fiction". Crime fiction is characterized by a hope of curbing the crime, and this control depends on the containment of the criminal other, through incarceration, death, etc.

The gaps and fissures that Scaggs mentions are indicative of a writerly text insofar as they lay bare the ideology at work and resist, subvert and, ultimately, topple it. However, as I will demonstrate below, drawing on Frederic Jameson and Pierre Macherey, Paretsky's 
Breakdown (2012) contains breaks in its realist narrative which betray the failure of the text at resistance and containment.

\section{SEDIMENTATION, the HARD-BOILED and the GOTHIC}

As Makinen points out in Feminist Popular Fiction, "Generic fiction has to subscribe to certain conventions in order to be accepted as generic fiction" (17). This apparently commonsensical statement contains a crucial matter which affects the way one views feminist appropriations of the hard-boiled genre. When certain features turn into the tropes of a genre, it becomes essential to retain those features or risk losing the integrity of that genre. A feminist fiction that fails to have a crime that is finally solved by the detective, for instance, might be good fiction but it will not be considered detective fiction. To begin, a crime and a detective are needed, and the expectations and conventions which have developed over the years should be dealt with by the author. The writer may choose to adapt them rather than simply adopt them, of course. "This series of expectations between audiences, writers and publishers marketing the fiction, is the formula or format of that genre". Such rules, needless to say, may be modified but not broken. And it is readily manifest that each generic formula includes certain ideological implications and assumptions. However, they are not cast in stone and are open to change, rising and falling with the waves of culture and politics. Makinen illustrates such generic evolution as follows:

Fairy tales, for example, embodied an aristocratic ideology of appropriate behavior for children in France during the eighteenth century, shifted to conveying a bourgeois view during the industrialized nineteenth century in Germany and England, and were open to a feminist appropriation in the late twentieth century, at a moment when society is undergoing huge changes in relation to gender. (17)

What is important to note here is that although genres are adaptable, they are constantly in flux, bringing together the conventions they used to subscribe to with the conventions they have adopted in their present mode.

In chapter two of The Political Unconscious, "Magical Narratives: on the dialectical use of genre criticism", Frederic Jameson offers a discussion on the conservative and the transformable aspects of genre fiction. Jameson discusses romance literature from medieval times to the eighteenth century, but his model is applicable to the hard-boiled detective fiction as well. Jameson describes the genres as "literary institutions," that is, as "social contracts between a writer and a specific public" (106). He argues that

by means of radical historicization, the 'essence', 'spirit', 'worldview', in question is revealed to be an ideologeme, that is, a historically determinate conceptual or semic complex which can project itself variously in the form of a protonarrative, a private or collective narrative fantasy. (115)

These "ideologemes" are not fixed for each genre. He holds that genres are transformable: for instance, the medieval romance can be "reinvented" in the eighteenth century by replacing the medieval magic with theology and an emerging psychology. The basic format remains the same but the "ideologemes" shift because of the new historical context. Of course, this shift is neither clear nor distinct. And more importantly, in such transformations some of the earlier ideological implications are carried over as a kind of residual "sediment": 
Let us now look more closely at this type of construction, which we will designate as a model of formal sedimentation . . . in its emergent, strong form a genre is essentially a socio-symbolic message, or in other terms, that form is immanently and intrinsically an ideology in its own right. When such forms are reappropriated and refashioned in quite different social and cultural contexts, this message persists and must be functionally reckoned into the new form ... The ideology of the form itself, thus sedimented, persists into the later, more complex structure as a generic message which co-exists - either as a contradiction or, on the other hand, as mediatory or harmonizing mechanism - with elements from later stages. (140-141)

Regarding Sara Paretsky's latest novel Breakdown (2012), a generic lineage other than the Hammett-Chandler tradition may be traced. Breakdown weaves together several narrative threads, each of which revolves around a mystery, a mystery which is Gothic in nature. The novel begins with a cemetery scene. Warshawski has been asked by her cousin to locate a few teenagers from a reading club who have skipped their club meeting and are out after curfew. She finds them in an abandoned cemetery performing an initiation ritual in the pouring rain under the full moon. Confronting the girls, she finds a recently killed man, lying on an elevated tomb with a dagger sticking out of his chest. One of the girls in this group turns out to be the granddaughter of a Jewish multimillionaire, Chaim Salanter, who is under constant attack by a news network for his mysterious past which is linked to WWII. The vehement news anchor, Wade Lawlor, accuses Chaim of having betrayed his own family to the Nazis in order to flee Poland and come to America. As Warshawski begins to explore the case of the dead man (who turns out to have been a morally corrupt PI) and to follow the clues left behind by her bipolar friend, Leydon Ashford, who has been seriously injured by an unknown assaulter in a church and is comatose for most of the novel, she faces resistance by all the parties involved. Chaim offers to hire her not to investigate the case; Leydon's brother and mother threaten her and ask her to stay out of their business; and the mental hospital, where Leydon used to be in and where the dead PI had visited before his death and had had a quarrel with Leydon, is equally hostile to Warshawski. The novel reaches its climax as Warshawski discovers that twenty years ago, Lawlor (the Global Entertainment Network news anchor) had killed his sister because he was in love with her and she was in love with someone else, and so blamed the murder on a local kid who was mentally retarded. More importantly, she learns that this wrongly convicted boy, now a middle-aged man, is institutionalized in the same mental hospital that Leydon used to be in, and there exists a piece of evidence in the form of a newspaper photo that can prove all this.

As this brief synopsis suggests, all the mysteries center on repressed acts which involve sexual or incestuous motifs. Lawlor's case is clear enough. Having lost his father, ambivalent towards his drunkard mother, he clings to his sister as a mother-substitute and object of intense love. Seeing she is in love with another boy, and witnessing the sexual relationship which exists between them, he kills his sister, leaving her body afloat on the local lake, and lets the local fool, who is on friendly terms with Lawlor's sister and usually watches her sunbathe on the banks of the lake, take the blame. The theme of incestuous love found here closely resembles that of Gothic novels of late-seventeenth and early-eighteenth centuries. Lawlor attacks Chaim Salanter on accounts which could induce an intense sense of shame and guilt in Lawlor himself. He accuses Chaim of having indirectly killed his own family, a crime that Lawlor himself has committed as the reader finds out toward the end of the novel. Half-way through the novel, Warshawski gets to hear Chaim's own version of the story, a story which revolves around repressed sexual acts too. His story goes like this: having lost his entire family, left alone with his mother, Chaim, aged 13, is under the 
protection of a German officer who has taken a liking to his mother and has regular sexual intercourse with her. As if witnessing his mother having sex with the stranger were not enough, after his mother is also taken away to be executed, the officer keeps him in the barn because he has his mother's eyes and sexually abuses him.

The point common to both events is that a man oppresses a woman: Lawlor oppresses his sister to the point that he needs to be in absolute possession of her and ends up murdering her; the German officer, too, colonizes Chaim's mother's body and finally refuses to save her, lets her die, and even tries to substitute her by her son because he bears a physical resemblance to her. The crucial point in Breakdown comes when Lawlor, having learned of Warshawski's discovery, drugs her and pushes her down a slope into a lake on a stormy night, and yet she miraculously survives. The way the text announces her survival - and by implication the failure of the oppressive, patriarchal ideology - will be analyzed in the next section under Macherey's theory of literary production.

\section{IDEOLOGY and REALIST FICTION: Pierre Macherey's $A$ Theory of Literary Production}

In his $A$ Theory of Literary Production (published 1966 and translated 1978), Pierre Macherey demonstrates that contradiction is a condition of narrative. Ideology, though coherent and complete on the surface, is in fact inconsistent and contradictory, and the realist text, as an embodiment of ideology, is necessarily incomplete, and tries to hide its inconsistencies in the apparent fullness of narrative closure. Macherey proposes to inspect the process of its production; that is, not the private experience of the writer him/herself, but the mode of production, the materials and their arrangement in the work. Such an inspection aims at locating the point of contradiction within the text. Catherine Belsey summarizes Macherey's point like this:

The classic realist text is constructed on the basis of enigma. Information is initially withheld on condition of a 'promise' to the reader that it will finally be revealed. The disclosure of this 'truth' brings the story to an end. The movement of narrative is thus both towards disclosure - the end of the storyand towards concealment - prolonging itself by delaying the end of the story through a series of 'reticences', as Barthes calls them, snares for the reader, partial answers to the questions raised, equivocations (Macherey 1978:28-9; Barthes 1975:75-6). (Critical Practice 87)

Macherey bases his analysis on the limitations imposed by the genre on the literary work in the process of its production, arguing that the literary work "is composed from a real diversity of elements which give it substance" (Literary Production 49). Needless to say, fiction (especially realist narrative) for Macherey is closely linked to ideology, but he never equates the two. Literature is a specific type of textuality, but the language which constitutes the raw material of the text is the language of ideology. As a result, this language is incomplete, partial, and ultimately incapable of concealing the real contradictions it is trying to evade.

In its attempts to create a coherent and internally consistent fictional world, the realist text betrays its own incoherence, which is indicative of the failure of the ideology inscribed in its language. Macherey likens this divided and split text to the Lacanian subject, and thus 
draws a parallel between the breaks and silences of the work and the Freudian unconscious. The unconscious of the work is formed at its entry into a literary genre. The text, therefore, like a human subject, may enjoy only an illusory unity. It is noteworthy that it is the unconscious of the work, and not of the writer, which is under investigation here. In analyzing the novels of Jules Verne, Macherey notes that "if Jules Verne chose to be the spokesman of a certain ideological condition, he could not choose to be what he in fact became" (94).

Sara Paretsky's Breakdown (2012), as a realist text written in the genre of the hardboiled detective fiction, lends itself to a Machereyian analysis perfectly. Within the narrative, which concerns the feminist V. I. Warshawski's unearthing of the oppressions imposed in most cases by men on women, there insists an older and contrary ideology which the consciousness of the text clearly rejects. The narrative closure is reached when Warshawski has solved the enigmas and arranged for the criminal news anchor Wade Lawlor to be prosecuted and arrested (though it is admitted in the text that his punishment will most probably fall short of his crimes). Nevertheless, Warshawski's success at surviving Lawlor's oppressive activities, which include drugging her and pushing her down a steep slope into a lake, and at finding evidence to incriminate him is exactly where the realist narrative text of this novel experiences a fissure.

\section{CONCLUSION: Breakdown in Paretsky's latest novel Breakdown (2012)}

As with all hard-boiled PI novels, Paretsky's Breakdown is narrated from the firstperson point of view. The advantages to this kind of focalization are numerous: the entire story is colored by the tough talk and wisecracks of the private eye and her private commentaries; a greater sense of sympathy and empathy is achieved as the reader is placed in the subject position (private eye/I); the PI becomes more credible as her private feelings and thoughts are revealed directly, making her more human; the process of reasoning and putting the pieces together involve the reader more deeply; the reader's limited knowledge approximates the investigator's, contributing to more suspense; and so on. Manipulation of the narrative point of view, therefore, is closely associated with the realism, suspension and credibility intended in detective fiction.

Although Breakdown is narrated throughout in the voice of V. I. Warshawski herself, one chapter parts with this point of view, thus introducing a break in the perspectival coherence of the text. Right after Lawlor's abduction and disposal of Warshawski in chapter 50 , the text presents the reader with a live news program led by V. I.'s journalist friend Murray in the third person point of view which begins like a memorial service for or a tribute to the dead V. I. By the end of the chapter, of course, the reader finds out that the protagonist is alive, though in poor health, and the program has been an elaborate hoax. But what justifications exist for this incoherence in the narrative point of view?

An obvious explanation is that Paretsky chooses to write this chapter in the thirdperson point of view to build maximum suspense as the readers will be momentarily deluded into thinking that Warshawski is really dead and that is why she cannot tell us the rest of the story. However, this opens a can of generic and ideological worms. The conventions of the hard-boiled genre necessitate the victory of the PI over the criminals. If, for a moment, the reader believes that this particular PI has lost her life in failure, it must be admitted that the feminist and counter-patriarchal vision of the series has ended up in failure as well. On the 
other hand, if the reader does not believe that Warshawski has died and thus sees through this chapter, then no extra suspense will be achieved through the third-person point of view. It can be concluded, therefore, that the reader will have to stop his/her logical thinking and read on in sheer anticipation. In other words, the reader needs to assume a position of complete ignorance for this third-person narrative to be successful. And this is certainly far from an adroit manipulation of the point of view.

What other justification may underlie this textual gesture? It is one of those fissures that Macherey postulated in A Theory of Literary Production. Although the consciousness of the text is announcing the triumph of the feminist PI, the unconscious of the text holds her dead, and allows her to continue living and working only if the consciousness of the text acknowledges it as a fantasy. Chapter 51 shifts the point of view to foreground its fantasydriven quality, admitting to the powerful presence of the ideology which has been carried like sediment, as Jameson has argued, along the generic stream whose sources are both the Gothic revival of the late-eighteenth century and the macho, misogynistic hard-boiled detective fiction of the early-twentieth century.

\section{References}

[1] Belsey Catherine. Critical Practice. New York and London: Routledge, 1988.

[2] Bertens Hans and D'haen Theo. Contemporary American Crime Fiction. New York: Palgrave Macmillan, 2001.

[3] Brunsdale Mitzi M. Gumshoes: A Dictionary of Fictional Detectives. London: Greenwood Press, 2006.

[4] Christiansen Scott R. "A Heap of Broken Images: Hardboiled Detective Fiction and the Discourse(s) of Modernity." The Cunning craft: original essays on detective fiction and contemporary literary theory. Ed. Walker Ronald G. and Frazer June M. Illinois: Western Illinois University, 1990.

[5] Frederic Jameson. The Political Unconscious: narrative as a socially symbolic act. London and New York: Routledge, 1983.

[6] Herbert Rosemary. Whodunit? A Who's Who in Crime and Mystery Writing. Oxford: Oxford University Press, 2003.

[7] Horsley Lee. Twentieth-Century Crime Fiction. Oxford: Oxford University Press, 2005.

[8] Knight Stephen. Crime Fiction: 1800-2000. New York: Palgrave Macmillan, 2004.

[9] Macherey Pierre. A Theory of Literary Production. Trans. Kegan Paul. New York and London: Routledge, 1978.

[10] Makinen Merja. Feminist Popular Fiction. New York: Palgrave Macmillan, 2001.

[11] Paretsky Sara. Breakdown. New York: Penguin Group (US), 2012.

[12] Pepper Andrew. "The 'Hard-Boiled' Genre." A Companion to Crime Fiction. Ed. Rzepka Charles J and Horsley Lee. Oxford: Wiley-Blackwell, 2010. 
[13] Scaggs John. Crime Fiction. New York and London: Routledge, 2005.

[14] Symons Julian. Bloody murder: from the detective story to the crime novel. London: Penguin Books, 1974.

[15] Traylor James L. and Collins Max Allan. One lonely knight: Mickey Spillane's Mike Hammer. Ohio: Bowling Green State University Popular Press, 1984. 